\title{
Investigation of Coffee Export Dynamics in Indonesia
}

\author{
Muhammad Idham Sofyan', Toto Edrinal Sebayang², \\ Viani Khairunnisa Syafni ${ }^{3}$ \\ Bina Nusantara University ${ }^{1,2,3}$ \\ Email korespondensi: muhammad.sofyan@binus.ac.id
}

\begin{abstract}
The aim of this research is to discover the factors that influence the export volume of Indonesian coffee, the response of Indonesian coffee exports to shock variables that affect $i t$, and the contribution of the variables affecting the coffee export to the change of export variables in Indonesia. The study used only secondary data (time series) and the data was collected from The Central Bank of Indonesia (BI), Central Bureau of Statistics (BPS) and International Coffee Organization (ICO). This study takes a monthly period starting from 2010: M01 to 2015: M12 by using the Vector Error Correction Model (VECM) analysis. The result of this research indicates that the data at the first difference is stationer and that there exist cointegration among the variables. While the Granger Causality test shows that there is a two-way relationship between domestic coffee prices and international coffee prices and the occurrence of a direct relationship between the domestic coffee price to the export volume of Indonesian coffee. The Impulse Response Function states that the shock of each variable will produce a sharp shock at the beginning of the period but will reach a stable point at the end of the period. The result of Factor Error Variance Decomposition analysis shows that the shock variables that affect it are still dominated by the variable itself
\end{abstract}

Keywords: coffee; exports; VECM

Received: 3 September 2018

Reviewed: 27 September 2018

Accepted: 5 Oktober 2018

Published: 31 Oktober 2018

\section{BACKGROUND}

The export volume of Indonesian coffee and Indonesian coffee production has fluctuated with a declining trend, especially back in 2013-2015. According to the Association of Indonesian Coffee Exporters and Industry (AEKI), Indonesia experienced an upward trend in export volume and coffee production from 2010 to 2013. In 2013, Indonesia's coffee exports totaled 534,023 tons with the production of 675,882 tons. This amount was the highest number during the period of 2010 to 
2015. A year later in 2014, both the volume of exports and Indonesia's coffee production declined sharply to 381,816 tons and 643,857 tons respectively. This can be seen in Figure 1. (AEKI, 2016).

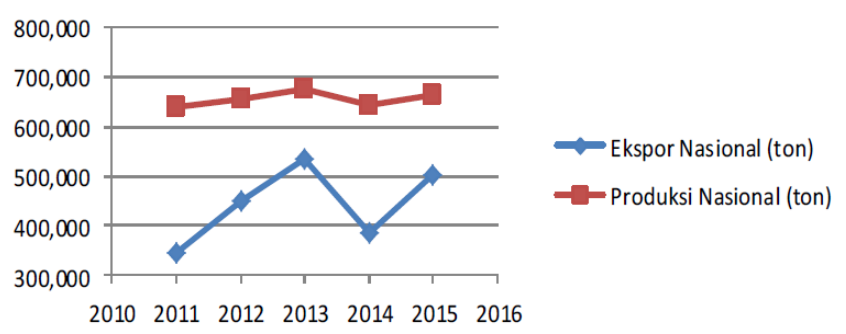

Source: (Asosiasi Eksportir dan Industri Kopi Indonesia, 2016)

Figure 1. Indonesia's Export Volume Trend and Coffee Production, Year 2010-15

In the European region, Finland has the highest coffee consumption and then followed by Canada in North America and last the Asian continent occupies the lowest position in coffee consumption in 2010. Along with the improving world economy and increased lifestyle, there is also an increasing Coffee demand from year to year. However, the increasing demand growth from the country is not followed by the growth of production in Indonesia. Indonesian coffee production has not responded significantly to the world's coffee demand. The vast amount of land that Indonesia owns has not been fully utilized to produce coffee. Based on the Indonesian Ministry of Agriculture (MOA) data in 2013, the amount of area that is utilized to produce coffee in Indonesia has reached 1.24 million hectares of land with a total production of 675,881 tons. The amount of land to produce coffee increased to about 1.254 million hectares in 2015 with a total production of 739,000 tons. Based on these data, currently, Indonesia's coffee productivity is only around 0.589 tons per hectare. Compared to Vietnam, the current productivity of Indonesian coffee per hectare is relatively low. Currently, the total amount of land that produces in Vietnam is only about 550,000 hectares. However, using half of the land area that is used in Indonesia, that amount of land in Vietnam produces around 1.65 million tons of coffee. In other words, every hectare of coffee land in Vietnam produces around 3 tons of coffee, which is significantly higher compared to Indonesia (GAEKI, 2016).

According to Shabrina (2016), about 95\% of Indonesia's coffee exports are in the form of green coffee. The remaining $5 \%$ consists of roasted coffee, instant coffee, ground coffee, and others. Most Indonesian coffee exports consist of Robusta coffee species with a total percentage of $93 \%$, while the remaining $7 \%$ is Arabica coffee. Around $67 \%$ of Indonesian coffee is exported to the world market, while the remaining $33 \%$ is used to meet the needs of domestic consumption. Most of the coffee is processed into coffee powder, instant coffee, and mixed coffee. Currently, Indonesian coffee exporters still rely on coffee beans as export priorities, 
while processed coffee has still not become a priority. The world coffee market is more receptive to raw coffee beans compared to processed coffee, simply because the processed coffee in each country is different so that the country is not necessarily compatible with Indonesian processed coffee. Based on statistics from the Gabungan Asosiasi Ekspor Kopi Indonesia, Indonesia occupies a strategic position in the world coffee trade, as Indonesia is included in the five largest coffee exporting countries in the world, as shown in Table 1 (GAEKI, 2016)

Table 1. Production and World's Percentage of Coffee Production

\begin{tabular}{clcc}
\hline No. & Country & Production (Ton) & Share (\%) \\
\hline 1 & Brazil & 3.456 .000 & 35,5 \\
\hline 2 & Vietnam & 1.590 .000 & 18,4 \\
\hline 3 & Colombia & 595.620 & 7,4 \\
\hline 4 & Indonesia & 630.000 & 6,3 \\
\hline 5 & India & 379.000 & 4,2 \\
\hline
\end{tabular}

Source: Indonesian Agricultural Data and Information System (2012)

According to the Indonesian Agricultural Data and Information System Center, Indonesia ranks fourth after Brazil, Vietnam, and Colombia in the world coffee production. Referring to Table 1. above, Indonesia produces around 630.000 tons per year or equivalent to 6.3 percent of the world's total coffee production. This figure is still far behind when compared to Brazil as the main coffee exporter country where Brazil currently is the largest coffee producer in the world with a total production of 3 million tons in 2012 which is equivalent to $35.51 \%$ of the world's coffee production in the same period. On the other hand, Indonesia with its vast land has the potential to increase their coffee production. However, from between 2012 to 2015 the volume of Indonesian coffee exports is continuously decreasing (GAEKI, 2016). The upsurge in Indonesian coffee export volume is thought to be due to several factors such as domestic coffee prices, international coffee prices and the Rupiah exchange rate against the US Dollar.

Based on the above facts, Indonesia's coffee production is a commodity that has high competitiveness with foreign coffee commodities and has the potential to increase foreign exchange, therefore it is necessary to conduct research that is related to the factors influencing Indonesian coffee exports and how much influence these factors, in turn, are influencing Indonesian coffee exports in both the short and long term.

The aim of this research is to analyze the response of Indonesian coffee exports to the shock variables that affect it in order to understand the contribution of variables that affect coffee exports on changes in Indonesian coffee export variables. 


\section{RESEARCH METHOD}

This study uses secondary data that consists of quantitative time series data with monthly data collected from 2010: M1 to 2015: M12. The rupiah exchange rate against the US dollar is obtained from Bank Indonesia which can be found at www.bi.go.id. In addition, there are also domestic coffee commodity price data and international coffee commodity prices which the authors have obtained from the International Coffee Organization (ICO) at www.ico.org page and Indonesian coffee export volume from www.bps.go.id. The problems in this research study will be analyzed by using the Vector Auto Regression (VAR) or Vector Error Correction Model (VECM). The Vector Auto Regression (VAR) equation model, built by minimizing the theory approach with the aim of capturing the economic phenomenon well. Thus, VAR is a non-structural model or is a non-theoretical model. VAR has different model shapes and is used and divided within this research into four stages (Ghozali, 2014; Widarjono, 2013; Winarno, 2011):

Non-stationary test of data is using Augmented Dickey-Fuller (ADF) test. If the result of the test is stationary at the level, VAR can be continued at the level and can continue to the next analysis. If the result is not stationary, or in other sense, it contains the root of the unit at the level, the differential drawing is done until the stationary data.

Determining the optimal Lag (time interval) is using the Akaike Information Criteria (AIC). The Cointegration test is conducted to determine whether the data in the model is cointegrated if the result of the test. If there is no cointegration, VAR analysis can be done in a different form to the estimation model formed. If there is cointegration, VAR analysis with Vector Error Correction Model (VECM) can be done.

The conducted analysis in the VAR model includes: (1) Granger Causality Test, determines the causality relationship between each variable is analyzed either in one direction or simultaneously; (2) Impulse Response Function Analysis (IRF), is an analysis to determine the effect of shock (shock) of a variable against other variables by changing a standard deviation by forecasting several periods ahead. (3) Analysis of Forecast Error Variance Decomposition (FEVD), determines the portion of influence in the form of the percentage of each variable to other variables also with the forecasting some periods ahead.

\section{RESULTS AND DISCUSSIONS}

\section{Unit Root Test}

The estimation starts by checking either the variables are stationary or not and the Augmented Dickey-Fuller (ADF) test was used for testing the stationary of variables. If the calculated value of the $\mathrm{ADF}$ t-statistic of each variable is less than the absolute critical value of MacKinnon at the confidence level of $1 \%, 5 \%$, and $10 \%$ then the data is said to be non-stationary or contains the root unit. Conversely, if the t-statistical value of ADF is greater than the critical value of MacKinnon then 
the data does not contain the root unit, or the data is stationary. Non-stationary data needs to be withdrawn until the data is stationary.

It can be seen in Table 2. that there is only one variable that can be called stationary i.e. the variable of the exchange rate, while other variables not yet fulfill criteria as stationary data at level. Therefore, it is necessary to test the root of the unit at the first differentiation level to get the whole variable is stationary. Table 3. shows the results of the ADF test at the first differentiation level, it was found that all variables had an absolute ADF t-statistic value greater than the critical value of MacKinnon at the level of $1 \%, 5 \%$, and $10 \%$, hence it can be concluded that the data is stationary at first difference.

Table 2. Unit Root Test of Variables at Level

\begin{tabular}{cccccc}
\hline Variables & t-Statistic & \multicolumn{2}{c}{ Critical MacKinnon Value } & \\
\cline { 3 - 5 } & ADF & $\mathbf{1 \%}$ & $\mathbf{5 \%}$ & $\mathbf{1 0 \%}$ & \\
\hline Harga domestik & -0.614217 & -2.615093 & -1.947975 & -1.612408 & Not Stationer \\
\hline Harga ekspor & -0.896140 & -2.616203 & -1.948140 & -1.612320 & Not Stationer \\
\hline Kurs & 2.826542 & -2.615093 & -1.947975 & -1.612408 & Stationer \\
\hline Volume Ekspor & -0.709303 & -2.615093 & -1.947975 & -1.612408 & Not Stationer \\
\hline
\end{tabular}

Source: Authors (2017)

Table 3. Unit Root Test of Variables at First Difference

\begin{tabular}{cccccc}
\hline Variables & t-Statistic & \multicolumn{2}{c}{ Critical MacKinnon Value } & \\
\cline { 3 - 5 } & ADF & $\mathbf{1 \%}$ & $\mathbf{5 \%}$ & $\mathbf{1 0 \%}$ & \\
\hline Harga domestik & -7.573726 & -2.616203 & -1.948140 & -1.612320 & Stationer \\
\hline Harga ekspor & -11.00916 & -2.616203 & -1.948140 & -1.612320 & Stationer \\
\hline Kurs & -4.991855 & -2.616203 & -1.948140 & -1.612320 & Stationer \\
\hline Volume Ekspor & -7.513471 & -2.616203 & -1.948140 & -1.612320 & Stationer \\
\hline
\end{tabular}

Source: Authors (2017)

\section{Lag Optimal}

After the stationary test, it is then necessary to determine the optimal lag number to be used in the variables to be analyzed. Determination of lag length (time interval) is needed to determine the length of the period of influence on the other endogenous variables. Where results in lag length tests are determined by looking at the most number of stars in each optimal lag test, and also determined by the smallest Akaike Information Criteria (AIC) value.

In this test, the researcher takes the optimal lag reference on the AIC lag value contained in lag 3. Thus, indicates that the domestic coffee price variables, international coffee prices, and the rupiah exchange rate against the dollar require a transition time of about 3 months to significantly affect export volume coffee of Indonesia.

\section{Co-integration Test}

Cointegration test is a technique used to determine the relationship of the long-term balance of the variables studied. In this research, a cointegration test 
using Johansen's Cointegration Test method. The Johansen cointegration test uses two statistical tests: trace statistic and maximum eigenvalue. The decision making used in the Johansen cointegration test is to compare the calculated value of the test statistic with the critical value. If the test statistic test value is trace statistic and maximum eigenvalue greater than critical value 0.05 then it is concluded that the existence of cointegration. The Johansen cointegration test with trace statistic value and maximum eigenvalue stated that the value of each is greater than the significance value of $5 \%$. It states that there is cointegration in that variable.

\section{Granger Causality Test}

Granger Causality Test is an analytical technique that can determine the causality relationship between the variables studied. Assessment based on Granger causality test is if the probability value of the variable under study is smaller than the significance of alpha 5\% then it can be concluded that the null hypothesis is rejected, in other words, that there is a causality relationship between these variables. Based on the results, there is a causal relationship between domestic and international price variables, as well as between domestic and international price variables and export volumes.
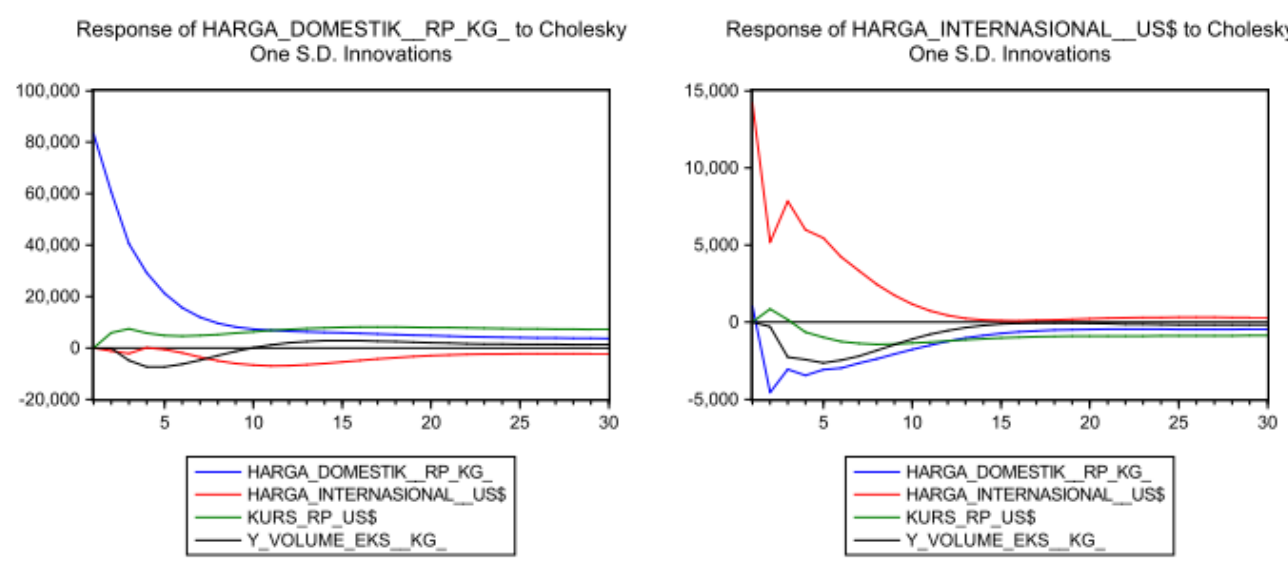

Response of KURS_RP_US\$ to Cholesky One S.D. Innovations
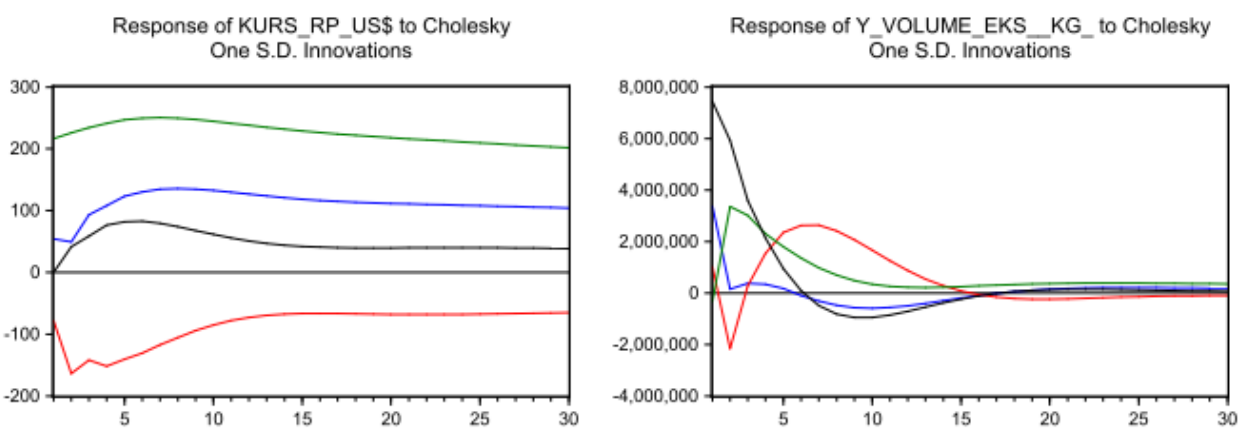

Source: Authors (2017)

Figure 2. Impulse Response Function Result 


\section{Impulse Response Function}

An Impulse Response or IRF analysis is an analytical tool used to look for the impact of shock variables one on the other variables. Using IRF will be able to estimate the impact of one of the shocks to other shocks present and future of all endogenous variables. From the above analysis it can be said that the shock of each variable will give a fluctuating shock at the beginning of the period, then the variable begins to adjust and decreases until it is constant at the end of the period. The result of Impulse Response Function is shown in figure 2.
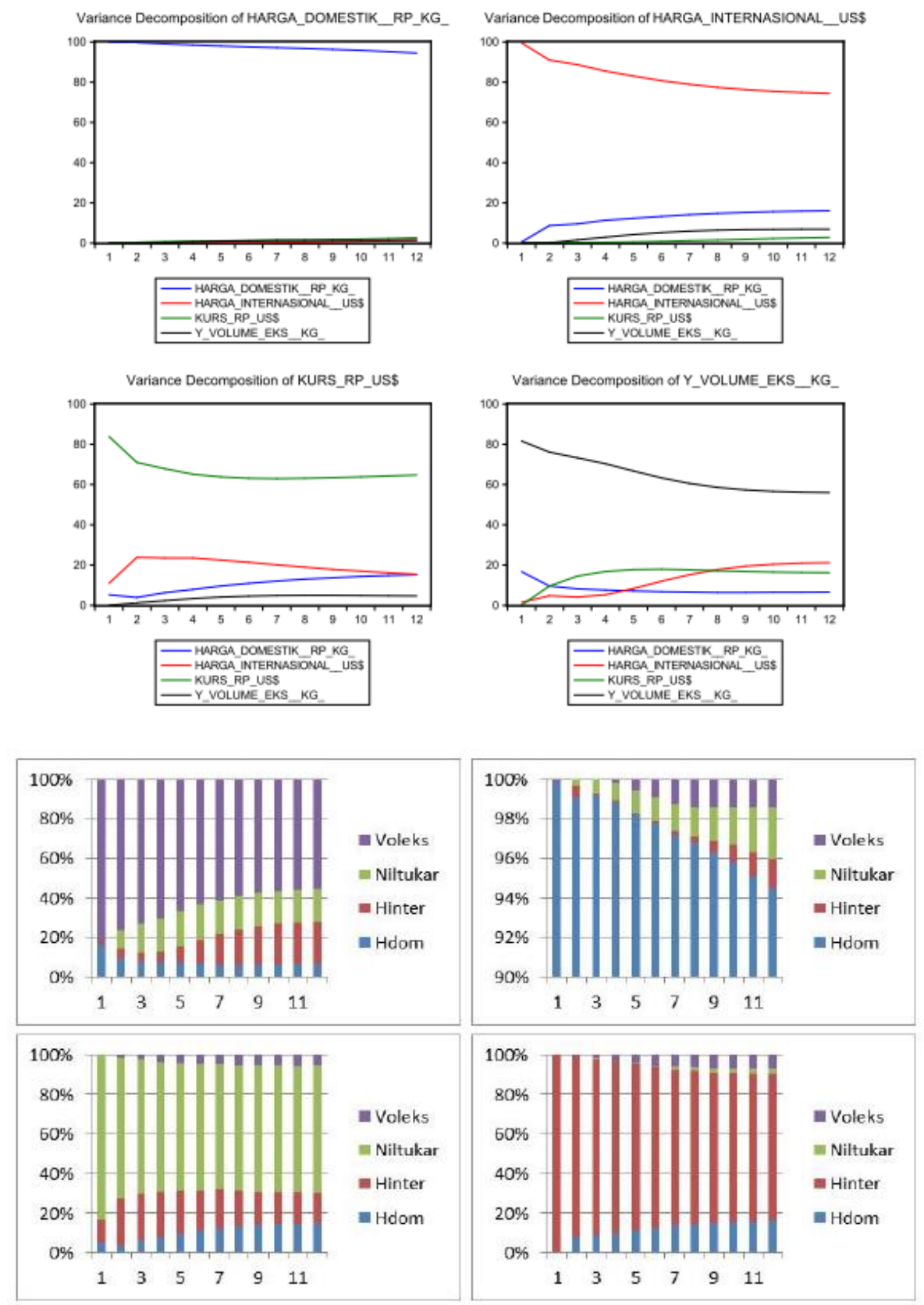

Source: Authors (2017)

Figure 3. FEVD Result 


\section{Factor Error Variance Decomposition}

The next analysis to be used is the Forecast Error Variance Decomposition (FEVD) method that can see the dynamic structure between variables in the VAR model. In this section is analyzed how the variant of a variable is determined by the role of other variables as well as the role of the variable itself. FEVD can see the magnitude of the difference between variants before and after a given shock, either shock from self or shock from other variables.

It can be seen on Figure 3 which is in the first period, the volume of the export volume itself explained $81.58 \%$, and the rest explained by domestic coffee price variable of $16.75 \%$, international coffee prices of $1.5 \%$ and $0.15 \%$ for exchange rate variables. The exchange rate variable had reached the highest level of $17.94 \%$ in the sixth period but gradually decreased until the end of the period only explained about $16.25 \%$. There is an upward trend in international coffee price variables which increased by about $19 \%$, contributing $21.14 \%$ at the end of the period. So, it can be concluded that the variant of Indonesia's coffee export volume affects the variable itself more than $50 \%$ and there is a significant contribution given by international coffee price variables which have percentage more than $20 \%$ and the exchange rate variable is $16 \%$.

\section{CONCLUSIONS}

Factors affecting Indonesia's coffee export volume are international coffee prices, domestic coffee prices and Rupiah exchange rates against the Dollar. Shocks on exchange rate variables and international coffee prices most affect the export volume of Indonesian coffee. This can be seen when the coffee export volume response to the variables is most significant. Indonesia's coffee export volume is strongly influenced by international coffee prices and the rupiah exchange rate against the dollar. In the short run, the export volume of Indonesian coffee is influenced by the volume of Indonesian coffee exports itself. However, in the long run, Indonesia's coffee export volume was affected by international coffee prices of $21 \%$ and the rupiah exchange rate against the dollar by $16 \%$. Other variables such as domestic coffee prices only contributed $6.5 \%$, and the remainder is explained by the volume variables of coffee export itself.

\section{Limitation and Future Research}

There is limited information available in Indonesia in regards of the specification of the coffee export commodity since there is only 1 (one) HS code 090111 available that covers all coffee categories, this results that researchers cannot classify the coffee specifically that will be exported. There are many organizations that directly participate in coffee exports but unfortunately, the data published has stopped only until 2015. By knowing the variables that affect the export volume of Indonesian coffee is expected government and relevant agencies able to maintain and expand the existing market. The volume of Indonesian coffee 
exports can be maximized by improving the quality of the coffee beans themselves. Because the quality of Indonesian coffee beans is still relatively low which resulted in low selling prices. By improving the quality of coffee beans will increase the base price of coffee beans so it will provide incentives for coffee farmers to coffee gardening. Increasing the quality of coffee beans will increase the selling price of Indonesian coffee beans.

The need for increased investment funding from the government so that the coffee beans can be processed first before being exported. Later coffee is exported not only in the form of seeds but in the form of processed coffee that has a distinctive taste of Indonesia. Thus, it can increase the added value of Indonesian coffee. The increase in value added will push the price to a better level which will increase the export volume of Indonesian coffee. Given more complete information about the export commodity of coffee either of its kind or form of coffee in the export itself. Thus, it will make it easier for other researchers or related agencies who want to analyze the dynamics of the volume of Indonesian coffee exports. For further research, it is recommended to explore other variables so that the research can provide more information about the impact to Indonesian coffee exports, such as production factor, local and seasonal market demand. Further researchers can also use other approaches to be able to explain more detail the determinants of Indonesian coffee exports.

\section{REFERENCES}

Food and Agriculture Organization of The United Nations. 2015. FAO Statistical Pocketbook Coffee 2015. Retrieved March 26, 2017, www.fao.org/3/ai4985e.pdf

Asosiasi Eksportir Kopi dan Industri Indonesia. 2016. Konsumsi Kopi Indonesia. retrived February 23, 2017, from Asosiasi Eksportir Kopi dan Industri Indonesia: http://aeki-aice.org/tabel_konsumsi_kopi_indonesia_aeki.html

GAEKI. 2016. Ketentuan Ekspor Kopi. Retrieved Februar 23, 2017, from GAEKI: http://gaeki.or.id/ketentuan-ekspor-kopi/

International Coffee Organization (ICO). 2016. Production. Retrieved March 3, 2017, from International Coffee Organization (ICO): http://www.ico.org/prices/po-production.pdf

International Coffee Organization (ICO). 2016. Export Statistics. Retrieved March 6, 2017, dari International Coffee Organization: http://www.ico.org/prices/m1-exports.pdf

Gozhali, Imam. (2014). Ekonometrika; Teori, Konsep dan Aplikasi dengan IBM SPSS 22. Semarang: Badan Penerbit Universitas Diponegoro. 
Gujarati, D. N. (2004). Basic Econometrics. Tata McGraw-Hill Education.

Shabrina, Wiendyan Anggun. (2016). Estimasi Hambatan Nontarif Dan FaktorFaktor Yang Memengaruhi Ekspor Kopi Indonesia Ke Negara Tujuan Utama. Institut Pertanian Bogor, Bogor.

Widarjono, Agus. (2013). Ekonometrika; Pengantar dan Aplikasinya. Yogyakarta: UPP STIM YKPN.

Winarno, Wing Wahyu. (2011). Analisis Ekonometrika Dan Statistika Dengan Eviews (Edisi 4). UPP STIM YKPN 